\title{
Google Classroom as a Distance Learning Media: Limitations and Overcoming Efforts
}

\author{
Suparjan ${ }^{1}$, Mariyadi ${ }^{2}$
}

DOI: 10.35445/alishlaH.v13i1. 460

\begin{tabular}{l}
\hline Info Artikel \\
\hline Keywords: \\
Distance learning \\
Problem Solving \\
Learning Constraints \\
Google Classroom
\end{tabular}

Kata kunci:

Mengatasi Kendala

Belajar Jarak Jauh

Kendala Belajar

Google Classroom

\begin{abstract}
This study investigates the obstacles that teachers faced using Google Classroom as a platform for Distance Learning (PJJ) during the COVID-19 pandemic at the elementary school level. This study also examines how elementary school teachers overcome the obstacles they experience while conducting distance learning through Google Classroom. This type of research is descriptive qualitative research. In-depth semi-structured interviews were used to collect data from 8 teacher respondents who actively use Google Classroom in teaching activities in Pontianak. The findings indicate that the obstacles faced by teachers during learning activities are limited facilities and infrastructure, lack of technical support, difficulties in controlling students, and lack of human resources. Teachers have made maximum efforts to overcome these obstacles by utilizing available facilities and infrastructure and affordable technical support and organizing independent training activities and peer-to-peer tutorial activities related to distance learning, such as controlling student learning and improving human resources quality.
\end{abstract}

\begin{abstract}
Abstrak
Penelitian ini bertujuan untuk mengetahui kendala yang dihadapi oleh guru dalam memanfaatkan Google Classroom sebagai wahana Pembelajaran Jarak Jauh (PJJ) selama pandemi COVID-19 di tingkat sekolah dasar. Studi ini juga meneliti bagaimana guru sekolah dasar mengatasi kendala yang mereka alami selama melakukan pembelajaran jarak jauh melalui wahana Google Classroom. Jenis penelitian ini adalah penelitian kualitatif deksriptif. Wawancara semi terstruktur secara mendalam digunakan untuk mengumpulkan data dari 8 responden-guru yang aktif menggunakan Google Classroom dalam kegiatan mengajar di kota Pontianak. Hasil temuan menunjukkan bahwa kendala yang dihadapi guru selama kegiatan pembelajaran adalah keterbatasan sarana dan prasarana, kurangnya dukungan teknis, kesulitan dalam mengontrol siswa, dan kurangnya sumber daya manusia. Upaya maksimal telah dilakukan oleh guru-guru untuk mengatasi kendala tersebut dengan memanfaatkan sarana dan prasarana yang tersedia dan dukungan teknis yang terjangkau, serta menyelenggarakan kegiatan pelatihan secara mandiri dan kegiatan tutorial antar teman sejawat terkait penyelenggaraan pembelajaran jarak jauh seperti cara mengontrol belajar siswa dan peningkatan kualitas sumber daya manusia.
\end{abstract}

\section{INTRODUCTION}

The COVID-19 pandemic in Indonesia has entered its second year since it was first identified in March 2020. The impact of the virus entry can still be felt today, especially in the field of education,

\footnotetext{
${ }^{1}$ Universitas Tanjungpura, Pontianak, Indonesia

Email: suparjan@untan.ac.id

${ }^{2}$ Indonesia Melestarikan Bahasa Ibu, Indonesia

Email: mariyadisahaja@gmail.com
} 
which still has to be implemented remotely or known as Distance Learning (PJJ) (Surat Edaran Menteri Pendidikan dan Kebudayaan Republik Indonesia Nomor 15 Tahun 2020 Tentang Pedoman Penyelenggaraan Belajar dari Rumah Dalam Masa Darurat Penyebaran Corona Virus Disease (COVID-19), 2020). Entering the start of learning 2021-2022, the government is launching face-toface learning by implementing health protocols planned to start in January or February 2021. Several regions have stated their ability to carry out face-to-face learning, including West Kalimantan province, which previously agreed. However, some areas of Kota Regencies are still not permitted, including Pontianak City, which can still carry out face-to-face learning.

Learning with the PJJ concept is not something new in the world of education. This learning model was first implemented in 1883 with the correspondence/transmission system learning known as the first generation. The development of technology gave changes to PJJ, which was implemented with the help of radio media in 1921. It was followed by the use of television in 1950, which was called the second generation. In the third generation, PJJ used computer assistance starting in 1982. The fourth generation is a combination of the first, second, and third generations. It is followed by the fifth generation based on artificial intelligence as in the existing PJJ media (Anthony, in Salma Prawiradilaga et al., 2016).

Learning under the PJJ concept at this time is learning that is carried out without face-to-face activities. Learning activities are implemented by applying online and offlinelearning models. (Surat Edaran Menteri Pendidikan dan Kebudayaan Republik Indonesia Nomor 15 Tahun 2020 Tentang Pedoman Penyelenggaraan Belajar dari Rumah Dalam Masa Darurat Penyebaran Corona Virus Disease (COVID-19), 2020). PJJ with the online model is learning that is carried out with the help of a network divided into two parts, namely synchronous and asynchronous (Pohan, 2020). Synchronous online PJJ is learning that emphasizes the timing of implementation between the teacher and students at one time. An example of learning like this is learning with video conferencing with the help of Google Meet or Zoom media. At the same time, asynchronous online learning is online learning that is not carried out simultaneously, such as the use of YouTube and Google Form. Meanwhile, offline learning activities which are part of PJJ are learning activities carried out without the involvement of the network (internet). This type of learning can be done with the help of worksheets, textbooks, and learning modules (Yuliani et al., 2020).

Many media can be used in PJJ, including social media converted into online learning media. One social media used is WhatsApp, which is widely used in elementary schools in West Kalimantan (Suparjan \& Mariyadi, 2020). In addition, some media that can be used in online PJJ include Google Classroom, which was built with the concept of a Learning Management System (LMS).

Google Classroom is one of the school choices in assisting online learning during the COVID19 pandemic. The use of these rides is based on several advantages; namely, they are easy to use, effective in using time, very responsive, and free (Iftakhar, 2016). In addition, students and teachers are also facilitated by cloud-based applications that can record and store all activities during learning. The limitations on teacher and student memory can be overcome so that all learning material can be maximally explored and can be reused when needed later (Ramadhani, 2020).

Google Classroom is proven to increase student motivation at SMKN 5 compared to the Edmodo application (Batita et al., 2019). Meanwhile, at SDN 1 Giling Pati, Google Classroom is proven to make learning more effective and improve learning achievement (Salamah, 2020). High school teachers in South Tanggerang admit that Google Classroom helps them in the teaching and learning process, namely managing student assignments, class management, and accommodating student interactions (Harjanto \& Sumarni, 2019).

Behind the convenience offered by Google Classroom, several obstacles were reported experienced by students of MAN 2 Kudus. Google Classroom does not have the facility to write formulas for science subjects. In addition, network problems and the lack of devices that support 
learning using Google Classroom are also obstacles teachers encounter when carrying out online learning activities (Hammi, 2017). Students experienced another block at SD Negeri o5 Silo, Jember Regency, who admitted that they had difficulty applying Google Classroom because they were still using the application for the first time. In addition, parents of students are also not good at Android to not guide students in the learning process through Google Classroom (Wulandari et al., 2020).

Some of the obstacles mentioned above are commonly found in the use of online media in learning. In-depth empirical research on the constraints of learning activities using Google Classroom media is still rarely done. Disclosing the obstacles in depth is very important to consider the widespread use of this media in online learning, especially its use as PJJ media during the COVID-19 pandemic. Thus, all general or unique problems that occur during teaching and learning activities involving Google Classroom can be found a solution. Disclosure about the efforts made can also help solve problems faced by schools when using or starting to develop these media. This study tries to complement previous research on the use of Google Classroom by looking at the constraints and efforts to deal with problems faced in its use.

\section{METHODS}

This research is a qualitative descriptive study. The descriptive research method aims to find facts in the field with appropriate and appropriate interpretations, including problems, circumstances, relationships, activities, views, attitudes, and stages in a phenomenon at the research location (Tarjo, 2019). The facts referred to in this study are about the obstacles to using Google Classroom as a medium or vehicle in PJJ during the COVID-19 pandemic at the elementary school level, and efforts to deal with it are further analyzed by an inductive approach that emphasizes meaning, reasoning, and so on regarding facts. Facts on the ground (Rukin, 2019). Points in the field are collected using semi-structured in-depth interview techniques, namely, interviews that place the researcher as a determinant of the direction of the conversation by developing questions from one issue or topic to more specific and precise questions according to the conditions faced in the field (Suwartono, 2014). The objects interviewed were eight elementary school teachers from 3 schools in Pontianak City. The selection of sources (in the future referred to as respondents) according to the sample selection instructions with a purposive sampling method allows researchers to select samples without specific limitations. The research objective is to uncover the obstacles faced using Google Classroom as PJJ media (Bernard in Purwanto, Pramono, Asbari, Santoso, et al., 2020). Respondents who have been selected have indeed used Google Classroom for at least one entire semester. The respondents' identity, both the school's location and personal data, are withheld to protect teacher privacy. The profiles of respondents in this study are detailed as follows.

Tabel 1. Respondent Profile

$\begin{array}{ccc}\text { Gender } & \begin{array}{c}\text { Level of } \\ \text { Education }\end{array}\end{array}$

\begin{tabular}{ccc}
\hline R1 & Male & S1 \\
\hline R2 & Female & S1 \\
\hline R3 & Female & S1 \\
\hline R4 & Male & S1 \\
\hline R5 & Female & S1 \\
\hline R6 & Female & S1 \\
\hline R7 & Female & S1 \\
\hline R8 & Female & S1 \\
\hline
\end{tabular}

When conducting research, the tools used to obtain data were writing instruments, voice recorders, and cell phones. The stationery is used to note essential parts of the interview process. A 
voice recorder is used to record the entire interview process. Mobile phones are used to make telephone calls, video calls, short messages to respondents, and recording interview activities. Handphone is used to avoid direct contact between researchers and respondents to prevent the spread of COVID-19. The data analysis technique in this research uses thematic data analysis techniques to find the themes obtained in the field, namely about the obstacles in using Google Classroom as a medium for PJJ and the efforts to handle them (Braun \& Clark in Heriyanto, 2018). Thematic data analysis techniques are considered appropriate to explore more profound and rigorously problems found in the field (Alhojailan in (Purwanto, Pramono, Asbari, Hyun, et al., 2020).

This research was conducted in three stages, namely the pre-research stage, the research stage, and the data analysis stage. The preliminary step in question is collecting initial findings regarding problems that occur in the field. It is continued by conducting research planning to collect additional information regarding school conditions, determining research objects, determining research locations, determining respondents, managing research equipment and tools, and research permit processing. The research stage in question is collecting data through semi-structured interviews with respondents and the location that has been determined in the pre-research stage. In the analysis stage, the data in the form of sound recordings that have been obtained from the research process are first transcribed into a written form. It is then inventoried to answer predetermined research questions, namely related to the obstacles faced by teachers in using Google Classroom as a Distance Learning medium. The sorted data is then displayed for further discussion and conclusions as to the conclusion of the research.

\section{FINDINGS AND DISCUSSION}

The data collected is displayed and analyzed to find the obstacles faced by teachers and students in using the Google Classroom during PJJ during the COVID-19 pandemic and efforts to overcome them. The data, along with the analysis, are shown below.

\section{The Constraints of using Google Classroom as PJJ Media}

This study succeeded in uncovering four significant themes about the obstacles faced by teachers, students, and parents in using Google Classroom as a learning medium. These constraints are infrastructure constraints, technical and other support constraints, weak student control constraints, and Human Resources (HR) constraints. These themes are further explained as follows.

\section{a. The Limitation of Facilities and Infrastructure}

Some respondents admitted that their obstacle in using Google Classroom as a learning medium during the COVID-19 pandemic was the lack of infrastructure. Interviews regarding these constraints can be seen in the following section.

“... the problem is on student devices brought by working parents...”(R1).

“... there was a disruption in the internet network, it was difficult to send information, assignments and learning materials. Because there was an incident all day, long GC experienced a problem because the student's account using the school admin was problematic ... The internet network was unstable, so that learning was intermittent ...”(R2).

“... the barrier may be the sometimes less stable network...” (R5)

"Children cannot enter with their cellphones so have to wait for their parents to come home." (R8) 
Based on interviews with eight respondents, four respondents stated that they experienced problems with facilities and infrastructure when using Google Classroom. These constraints are in the form of network constraints experienced by both teachers and students. This network constraint can be in the form of network instability, which makes the display on Google Meet disrupted, experiencing delays (delaying), or incomplete voice transmission from teachers or students. In addition, this network disruption also resulted in delays in sending files such as videos, photos, and other files from teacher to student and student to teacher. The trouble of sending material learning files from teachers to students resulted in the ineffectiveness of time, while network disruptions when sending from teaching students to students in the form of assignment results affected the teacher's assessment of students' compliance and discipline. These constraints are exacerbated by the absence of alternative learning media so that when the network is problematic in one day, learning will experience delays. Barriers regarding the network are consistent with online survey reports, which reveal that network constraints are one of the obstacles to implementing online learning (Anugrahana, 2020).

Further constraints regarding the facilities and infrastructure are supporting learning devices, namely Android mobile phones. In several places, schools and parents of students have coordinated about learning readiness to use Google Classroom, which is about facilities and infrastructure. Almost all parents agreed to provide the device. However, there are still some obstacles, such as devices that have to be used interchangeably so that students have to wait for other devices such as devices owned by parents. The problems regarding the availability of android devices were also found in Kumantan 013 Public Elementary School, where some parents of students did not have androids and sufficient quotas to carry out online learning (Anggianita et al., 2020).

\section{b. The Lack of Application Technical Support and Other Support}

Several respondents acknowledged technical obstacles from using Google Classroom as a learning medium during the COVID-19 pandemic. Interviews regarding these constraints can be seen in the following section.

"... the problem is that students forget their account passwords, so they have to contact the school operator. Often dies after one hour of use ...” (R1)

“... complaints from parents that sometimes their children find it difficult to enter when Google Meet starts because of signals or wrong accounts ... sometimes less time in teaching because the schedule has been set ... when correcting essays need extra because it focuses on children's writing which is sometimes difficult to read ...”(R3)

“... must socialize to parents and students who are still unfamiliar with GC, there are some parents/students who do not understand how to send assignments to GC, account problems that cannot join GC so teachers must explain and guide parents/students on how to fix it via online...”(R7)

"The only drawback is that usually, children cannot access it if the student account is not synchronized with the GC." (R8)

Based on interviews with eight respondents, four respondents reported technical problems when using Google Classroom during the learning process. Students mainly experienced these technical obstacles, namely, Gmail accounts that were still not synchronized with the Google Classroom application, so that students could not be invited and included in learning. This problem has an impact on the effectiveness of using wasted lesson hours to improve student accounts. This problem also occurs due to students forgetting the password to sign in to their Google Classroom account to create a new account, and the new account still hasn't synced to Google Classroom. 
The path taken by students who have problems entering Google Classroom is by contacting the school operator. However, the usual school operators consist of only 1 to 2 people, only able to handle five to ten students. Problems like this will be complicated for middle and upper-class students whom parents do not guide. So that the problem can drag on until the parents of students come and fix the problematic account. Regarding the obstacles to entering Google Classroom, you can see how they are handled in Classroom Help (Suport, 2021). Students who use Google Classroom with personal accounts can reset their passwords personally by following Google's instructions. In contrast, students signed in with a school account must contact the school to request a password reset.

Another technical obstacle is the lack of parental knowledge of Google Classroom, especially for low-level students who need parental assistance. Some parents have complained about not getting into Google Classroom, failing to get into Google Meet, not understanding how to upload videos of student assignments. This problem is motivated by the inability of parents to overcome the issues at hand.

\section{c. The Weak of Student Learning Control}

Some respondents acknowledged that there were obstacles, namely their difficulty controlling student learning from using GC as a learning medium during the COVID-19 pandemic. Interviews regarding these constraints can be seen in the following section.

"The downside, Google Classroom cannot make learning interactive” (R2)

"Involvement of students entering GC, rules that are not respected by students online, cannot open videos of students who do not want to open videos, so we don't know whether students are present in front of the screen."(R3)

"When learning takes place, not all children learn the material that is shared in GC ... it cannot ensure that the children understand the material well ... Children do not understand the material because children only read the material. Even though a video explanation from the teacher has accompanied it, not all children are listening" (R5)

The interview above shows the teacher's constraints in controlling students, both regarding discipline, learning motivation, and control over the level of students' ability to master the subject matter. Google Classroom does not provide teachers with an option to turn on video. The rule of student attendance and compliance in learning is deficient. This problem mainly occurs in learning that is carried out with the help of Google Meet. For example, students do not activate videos or leave lessons.

The control over compliance in carrying out instructions from teachers is also challenging to enforce through Google Classroom. The teacher cannot know whether students read the material that has been given or listened to the video provided by the teacher. The lack of Google Classroom features in enhancing interactive communication between teachers and students makes teachers unable to determine students' level of understanding.

\section{d. The Lack of Human Resources}

Some respondents admitted that they and some of their colleagues had difficulty using Google Classroom as a learning medium during the COVID-19 pandemic. These obstacles are also experienced by parents of students who are still unfamiliar with using the application. Interviews regarding these constraints can be seen in the following section. 
“... at first, many were confused. Especially parents. The average is almost all confused. Open can, but operate much more confused..." (R1)

“... parents and students who are still unfamiliar with GC, there are some parents/students who do not understand how to send assignments to GC, account problems cannot join ...”(R2)

The conversation fragment above illustrates that there are obstacles regarding Human Resources in using Google Classroom. These constraints occur in teachers, students, and parents. The barrier to the teacher is about the operation of the application further, such as how to manage classrooms, create questions, which many senior teachers experience. This situation is exacerbated by the lack of specific training on online learning applications, especially Google Classroom. Several teachers interviewed admitted that they had never received training at all using Google Classroom. Constraints also occur in students and parents of students. Some teachers revealed that at the beginning of implementing Google classrooms, many students and parents complained about technical things they did not understand, such as uploading videos, activating sound and video on Google Meet, or turning it off. This problem also occurs in SD Negeri 5 Silo, Jember Regency, which finds students and parents unable to operate the application (Wulandari et al., 2020).

\section{The Overcoming Obstacles in Using Google Classroom as PJJ Media}

This study succeeded in collecting some of the efforts made by teachers in dealing with the obstacles faced in using Google Classroom as a medium for PJJ. These efforts are further described as follows.

\section{a. $\quad$ The Overcoming Facilities and Infrastructure Constraints}

Some respondents said they had made several efforts to overcome the constraints of facilities and infrastructure in using Google Classroom as a learning medium during the COVID-19 pandemic. Interviews regarding efforts to overcome these obstacles can be seen in the following section.

“... We have offline classes too ... we have night classes for those who can't take exams with GC ... The school provides large wifi ... the wifi capacity is increased ... the teacher is given a quote from the school. We involve parents ... we coordinate several times ...”(R1).

The interview fragment above shows some of the efforts made by the teacher in dealing with the infrastructure and facilities constraints experienced when using Google Classroom. First, the school provides a choice of learning models other than online learning, namely learning offline. This learning is mainly for children who do not have the equipment. Second, carry out online learning in the afternoon or evening. This learning is specifically for implementing tests that students cannot follow to take the test on another schedule still. Third, coordination between schools and parents of students regarding the readiness of online learning tools through Google Classroom. This coordination is to determine the condition of the availability of the device about the possibility of the device being damaged, having to be used for other purposes, or other unexpected things. The use of offline learning to overcome the constraints of online learning facilities and infrastructure is also used at the early childhood and kindergarten levels in North Sumatra. The type of offline learning carried out is a home visit, which is by visiting students who do not have online learning facilities and infrastructure that are generally found in rural areas (Harahap et al., 2021).

\section{b. $\quad$ The Overcoming Technical and Other Supporting Constraints}

Some respondents said they had made several efforts to overcome technical obstacles using Google Classroom as a learning medium during the COVID-19 pandemic. Interviews regarding efforts to overcome these obstacles can be seen in the following section. 
"... the school purchases a premium account. One child was given a special email ... There were IT experts ... there were recruits ... so operators were helping ...”(R1).

“... we also use a premium account . ”(R2)

“... we use a lot of other media ...” (R6)

“..it must be socialized to parents and students who are still unfamiliar with $G C$, the teacher must explain and guide parents/students on how to fix it online"(R7)

The interview fragment above shows the school's efforts to overcome technical obstacles using Google Classroom as a medium for PJJ. Schools provide premium accounts that school operators manage to overcome problems with forgetting passwords, video activity on Google Meet that suddenly turns off, and uniform email for students and teachers. Schools reform school management by placing personnel who master information technology to become administrators or operators who handle student and teacher problems in online learning. Recruitment of IT personnel was also carried out to overcome the lack of school operators. In addition, teachers and schools continue to play an active role in understanding students and parents of students in using Google Classroom, both in uploading assignments and other matters related to technology usage. This application so that students or parents do not have to contact the school operator during the lesson.

c. $\quad$ The Overcoming Obstacles Weak Student Learning Control

Some respondents said that they had made several efforts to overcome the constraints of weak learning controls when using Google Classroom as a medium for PJJ. Interviews regarding efforts to overcome these obstacles can be seen in the following section.

“... We involve parents ... several times we coordinate.... each teacher must be absent

... we several times come to the student's house to provide motivation" (R1).

The interview fragment above shows an effort to overcome the weakness of student learning control, namely by coordinating with the parents of students to find solutions to the problems faced. Several teachers and homeroom teachers visited the students several times to motivate them to learn and identify the issues faced by students. Regarding student absence or student skipping from the ongoing lesson, the teacher admits that he always checks by doing lacks and always provides reinforcement to students who are known to be inactive in learning.

\section{The Overcoming Human Resources Constraints}

Some respondents said that the school had made several efforts to overcome Human Resources (HR) constraints using Google Classroom as a learning medium during the COVID-19 pandemic. Interviews regarding efforts to overcome these obstacles can be seen in the following section.

“... Initially there was training from the school ... There were IT experts..... so the operators were helping ...."(R1).

“...the teacher must explain and guide parents/students on how to fix it online.”(R7)

The conversation section above shows the efforts that schools and teachers have taken to overcome human resource constraints when using Google Classroom as a PJJ media, namely by providing skilled technology experts. The staff is also intended to deal with problems faced by students and parents when using Google Classroom. For teachers who have not mastered Google Classroom, schools have conducted initial training on the technical use of Google Classroom. In 
addition, teachers who have learned Google Classroom should also play an active role in understanding fellow teachers, students and parents of students who experience problems using Google Classroom. After receiving Edmodo instructional media training online, several studies have revealed that 30 teachers in Indonesia are more familiar with the media and are more enthusiastic about learning conducted using online media (Agustina \& Susanto, 2017).

\section{CONCLUSION}

This study succeeded in investigating the obstacles to using Google Classroom as PJJ media during the COVID-19 pandemic at the Elementary School level in Pontianak City. These constraints are: First, the constraints on the limited availability of facilities and infrastructure such as student equipment and networks. Second, technical support problems include difficulty logging into Google Classroom, forgetting passwords, difficulty uploading media, unstable networks, difficulty logging into Google Meet or suddenly leaving the account. Third, the problem is the lack of student control, such as students who do not activate videos, skip lessons, and do not do instructions instructed by the teacher. Fourth, human resource constraints, namely teachers, students, and parents, still have not mastered the use of Google Classroom. Efforts that have been made in overcoming the obstacles faced are: First, overcoming constraints on the availability of facilities and infrastructure, namely by holding offline learning, tests or night lessons, and coordinating with parents. Second, overcoming technical obstacles, namely providing premium google accounts, increasing teacher quota, increasing school quota, using other media assistance, and conducting socialization and understanding for teachers, students and parents and third, overcoming the problem of weak student control, namely by including parents, reinforcing students, and knowing more about the conditions experienced by students. Then, overcoming human resource constraints, namely by providing information technology technical personnel and playing an active role in finding solutions to teachers, students, and parents about problems using Google Classroom.

This research succeeded in uncovering the obstacles faced by elementary school teachers in Pontianak City when using Google Classroom in online learning during the COVID-19 pandemic. It can be used as a reference for schools that want or have used Google Classroom as a vehicle for distance learning to identify more-beginning and trying to find solutions according to the conditions that occur in the field. Further research on the use of Google Classroom to facilitate distance learning and the constraints that accompany it needs to be carried out by involving a larger sample size and a higher education level. Quantitative investigations also need to be carried out to support the conclusions of previous qualitative research in terms of constraints, causes, and ways to overcome them. The use of Google Classroom can be used as an alternative vehicle that can support learning and teaching activities remotely in the future.

\section{REFERENCES}

Agustina, N., \& Susanto, R. (2017). Persepsi Guru Terhadap Pengembangan Profesionalisme Melalui Pelatihan Media Pembelajaran Berbasis Edmodo. Prosiding Seminar Nasional Pendidikan Teknik Informatika, 2(1), 44-48. http://eproceeding.undiksha.ac.id/index.php/senapati/article/download/1171/879

Anggianita, S., Yusnira, \& Rizal, M. S. (2020). Persepsi Guru terhadap Pembelajaran Daring di Sekolah Dasar Negeri 013 Kumantan. Journal of Education Research, 1(2), 177-182. https://doi.org/DOI: 10.37985/joe.v1I2.18

Anugrahana, A. (2020). Hambatan, Solusi dan Harapan: Pembelajaran Daring Selama Masa Pandemi Covid-19 Oleh Guru Sekolah Dasar. Scholaria: Jurnal Pendidikan Dan Kebudayaan, 1O(3), 282-289. https://doi.org/10.24246/j.js.2020.v10.i3.p282-289

Batita, M. S. R., Wijoyo, S. H., \& Herlambang, A. D. (2019). Analisis Perbandingan Blended Learningberbasis Edmodo dan Google Classroom ditinjau dari Motivasi dan Hasil Belajar Siswa. Jurnal Pengembangan Teknologi Informasi Dan Ilmu Komputer, 3(4), 3756-3764. http://j-ptiik.ub.ac.id/index.php/j-ptiik/article/view/5023/2372

Hammi, Z. (2017). Implementasi Google Classroom pada Kelas XI IPA Man 2 Kudus. Universitas 
Negeri Semarang.

Harahap, S. A., Dimyati, D., \& Purwanta, E. (2021). Problematika Pembelajaran Daring dan Luring Anak Usia Dini bagi Guru dan Orang tua di Masa Pandemi Covid 19. Jurnal Obsesi : Jurnal Pendidikan Anak Usia Dini, 5(2), 1825-1836. https://doi.org/10.31004/obsesi.v5I2.1013

Harjanto, A. S., \& Sumarni, S. (2019). Teachers' Experiences On The Use Of Google Classroom. 3 Rd English Language and Literature International Conference (ELLiC), 3, 172-178. https://jurnal.unimus.ac.id/index.php/ELLIC/article/download/4704/4231

Heriyanto. (2018). Thematic Analysis sebagai Metode Menganalisa Data untuk Penelitian Kualitatif. Anuva: Jurnal Kajian Budaya, Perpustakaan, Dan Informasi, 2(317-324). https://doi.org/10.14710/anuva.2.3.317-324

Iftakhar, S. (2016). GOOGLE CLASSROOM: WHAT WORKS AND HOW? Journal of Education and Social Sciences, 3, 12-18. https://www.jesoc.com/wp-content/uploads/2016/o3/KC3_35.pdf

lengkap-kasus-pertama-virus-corona-di-indonesia?page=all

Surat Edaran Menteri Pendidikan dan Kebudayaan Republik Indonesia Nomor 15 Tahun 2020 Tentang Pedoman Penyelenggaraan Belajar dari Rumah dalam Masa Darurat Penyebaran Corona Virus Disease (COVID-19), (2020).

Pohan, A. E. (2020). Konsep pembelajaran daring berbasis pendekatan ilmiah. CV Samu Untung.

Purwanto, A., Pramono, R., Asbari, M., Hyun, C. C., Wijayanti, L. M., Putri, R. S., \& Santoso, priyono B. (2020). Studi ekspolratif dampak pandemi covid-19 terhadap proses pembelajaran online di sekolah dasar. EduPsyCounsJournal, 2(1), 1-12. https://ummaspul.ejournal.id/Edupsycouns/article/view/397

Purwanto, A., Pramono, R., Asbari, M., Santoso, P. B., Mayesti, L., Wijayanti, Hyun, C. C., \& Putri, R. S. (2020). Studi Eksploratif Dampak Pandemi COVID-19 Terhadap Proses Pembelajaran Online di Sekolah Dasar. EduPsyCounsJournal, 2(1), 1--12. https://www.researchgate.net/publication/340661871_Studi_Eksploratif_Dampak_Pandemi COVID-

19_Terhadap_Proses_Pembelajaran_Online_di_Sekolah_Dasar/link/5e979abe4585150839e 0239b/download

Ramadhani, R. (2020). Desain Pembelajaran Matematika Berbasis TIK: Konsep dan Penerapan (J. Simarmata (ed.)). Yayasan Kita Menulis.

Rukin. (2019). Metodologi penelitian kualitatif. Yayasann Ahmar Cendikia Indonesia.

Salamah, W. (2020). Deskripsi Penggunaan Aplikasi Google Classroom dalam Proses Pembelajaran. Jurnal Penelitian Dan Pengembangan Pendidikan (JPPP), 4(3), 533-538. https://doi.org/http://dx.doi.org/10.23887/jppp.v4i3.29099

Salma Prawiradilaga, D., Ariani, D., \& Handoko, H. (2016). Mozaik Tenologi Pendidikan: Elearning. Prenadamedia Group.

Suparjan, \& Mariyadi. (2020). Proses Belajar Mengajar Selama Pandemi COVID-19 Pada Tingkat Sekolah Dasar Di Kalimantan Barat. Jurnal DIDIKA : Wahana Ilmiah Pendidikan Dasar, 6(2), 314--331. http://e-journal.hamzanwadi.ac.id/index.php/didika/article/view/3044

Suport, G. (2021). Pemecahan masalah untuk siswa. Google Classroom. https://support.google.com/edu/classroom/answer/6315899

Suwartono. (2014). Dasar-dasar metodologi penelitian. CV Andi Offset.

Tarjo. (2019). Metode Penelitian. Deepublish.

Wulandari, R., Widiatsih, A., \& Muarif, S. (2020). Pemanfaatan Google Classroom dalam Penilaian Autentik Studi Kasus SD Negeri Sidomulyo 05 Silo Kabupaten Jember. Rekayasa: Journal of Science and Technology, 13(2), 187-196. https://doi.org/https://doi.org/10.21107/rekayasa.v13I2.5904

Yuliani, M., Simarmata, J., Susanti, S. S., Mahawati, E., Sudra, R. I., Dwiyanto, H., Irawan, E., Ardiana Yudhi, D. P., Muttaqin, M., \& Yuniwati, I. (2020). Pembelajaran daring untuk pendidikan: Teori dan penerapan. Yayasan Kita Menulis. 